\title{
Physico-chemical Meat Qualities of Loin and Top Round Beef from Holstein Calves with Different Slaughtering Ages
}

\author{
Soohyun Cho*, Sun Moon Kang, Pilnam Seong, Geunho Kang, Sunho Choi, Engki Kwon, \\ Sungsil Moon ${ }^{1}$, Donghun Kim, and Beomyoung Park \\ National Institute of Animal Science, Rural Development Administration, Suwon 441-706, Korea \\ ${ }^{1}$ Sunjin Meat Research Center, Ansung 456-913, Korea
}

\begin{abstract}
The objective of this study was to investigate the physico-chemical and sensory properties of loin ( $m$. longissimus dorsi) and top round (m. semimembranosus) beef from 3-, 6-, 9-, and 12 mon-old Holstein calves. For both loin and top round muscles, the moisture contents were decreased, whereas the protein and fat contents were increased, as the slaughtering age increased. In terms of meat color, for both muscle types, CIE L* values were decreased, whereas CIE a* values and myoglobin content increased as the slaughtering age increased. $\mathrm{pH}$ values were significantly higher in the 3 mon-old group than in the other groups. The Warner-Bratzler shear force (WBSF) values were lowest for loin muscles from the 12 mon-old group; however, there was no significant difference for top round muscle among the 4 age groups. Cooking loss for both loin and top round muscles were significantly higher for the 3 mon-old group than for the other groups. The water holding capacity (WHC) of both muscles were highest for the 12 mon-old groups $(p<0.05)$. In fatty acid composition of the 12 mon-old groups, loin muscles had significantly higher levels of C14:0, C16:1n7, C18:1n9, and mono-unsaturated fatty acids (MUFA), and top round muscles had significantly higher levels of C16:1n7, C18:1n7, C18:1n9, MUFA, MUFA/SFA. Loin muscle from the 3- and 12 mon-old groups had significantly higher scores for tenderness and overall likeness. Top round muscle from the 9- and 12 mon-old groups had significantly higher scores for overall likeness than those from the other age groups.
\end{abstract}

Keywords: Holstein calves, meat quality, fatty acids, sensory property

\section{Introduction}

In the traditional veal calf rearing system, the animals are kept in individual, narrow, and short crates and receive a liquid milk replacer with a low iron $(\mathrm{Fe})$ content up to the age of 6 mon (Le Neindre, 1993). Over the last 50 years, the veal industry has undergone a number of changes, in particularly in production systems with the introduction and acceptance of grain-fed and heavier calves and there has increasingly been a movement from individual pens to group housing (Ngapo and Gariépy, 2006). The reasons for these changes are a greater consideration for the well-being of the animals and the public perception of the industry.

Veal is a significant meat source and is of substantial

*Corresponding author: Soohyun Cho, Animal Products Research and Development Division, National Institute of Animal Science, Rural Development Administration, Suwon 441-706, Korea. Tel: +82-31-290-1703, Fax: +82-31-290-1697, E-mail: shc0915@korea.kr value to some countries, notably France, Italy, the Netherlands, and to some regions of North America, specifically Québec and Ontario in Canada and Indiana, Maryland, Michigan, New York, Ohio, Pennsylvania, and Wisconsin in the USA (Ngapo and Gariépy, 2006). The Canadian Agri-Food Research Council (1998) refers to these animals, which are destined for slaughter or for other rearing facilities and feeding programs, as "bob calf," "drop calf," or "baby calf." Both the European Commission (2003) and the Canadian Agri-Food Research Council (1998) have defined "milk-fed veal" as calves fed milk-based feeds. The European Commission differentiates veal as meat derived from calves of 16-19 wk of age (Ngapo and Gariépy, 2006). Wilson (2004) coined the term "non-special-fed veal" and defined these calves as being fed a variety of diets, including milk replacer, grain, and forage, and as being marketed at live weights of approximately $70-180 \mathrm{~kg}$. "Grain-fed veal" calves are generally defined as calves fed a milk-based diet for the first $6 \mathrm{wk}$, and then a whole-grain corn- and protein-supplemented diet for the remaining portion of the production period. Aus-Meat 
Limited of Australia (2005) more broadly defined veal as calves that demonstrate no evidence of eruption of permanent incisor teeth, showing youthfulness and veal color, weighing no more than $150 \mathrm{~kg}$ in carcass weight, and in males showing no evidence of secondary sexual characteristics.

Although the overall domestic beef production in 2013 increased by $42.4 \%$, beef production from Holstein bulls and steers decreased by $21.2 \%$, when compared to those in 2010 (KAPE, 2014). The average slaughtering times of Holstein steer were from 20 to 22 mon. At this time, the frequencies of quality grading above grade 1 for Holstein steers were only $9.0 \%$ in 2013. Some Holstein dairy farmers attempted to produce the highly marbled Holstein steer beef using a longer feeding period, but, in the Korean beef grading system, this was not financially advantageous for Holstein farmers, due to the expensive feeding cost and low feeding efficiency. Currently, Holstein dairy farmers face serious challenges when they have new-born, male veal, given the unstable market price and low valuation of this product in the domestic beef market. The farmers found a solution to advance the slaughtering time by production of calf beef; however, this has been little studied. A number of publications has focused on changes in the production systems to improve feed efficiency, weight gain, and carcass characteristics in veal farming, but meat quality attributes have rarely been assessed.

Therefore, the objective of this study was to investigate the physico-chemical and sensory properties of loin $(m$. longissimus dorsi) and top round ( $m$. semimembranosus) beef from 3-, 6-, 9-, and 12 mon-old Holstein calves.

\section{Materials and Methods}

\section{Sample preparation}

Twenty pure Holstein male calves were used in this study. The animals arrived at the Holstein dairy farm experimental unit in Ansung city of Gyeonggi-do at $20 \mathrm{~d}$ of age and the calves were fed a milk replacer based on sprayed skimmed milk powder, without receiving any other feed or supplement. The calves, grouped by birth weight and birth date, were housed indoors and penned in 4 groups ( 5 animals/pen) with drinking and feeding troughs at their disposal.

The following diet was provided: a milk replacer for 20-90 d, early calf feed (CP 19\% and TDN 71\%) for 70$90 \mathrm{~d}$, middle calf feed (CP 17\% and TDN 71\%) and cereal straw ad libitum for 90-270 d, and growing period feed (CP 14\% and TDN 71\%) ad libitum until the age of 12 mon. The animals were weighed at 3, 6, 9, and 12 mon (at the end of the experimental period on the day before slaughter). After slaughter, the right side of each carcass was hung by the Achilles tendon and cooled at $4^{\circ} \mathrm{C}$. Approximately $24 \mathrm{~h}$ post-mortem, the right side of the carcass was deboned and trimmed as directed in the domestic fabrication manual (National Livestock Cooperatives Federation, 1998). The loin (m. longissimus dorsi, LD) and top round ( $m$. semimembranosus, SM) were separated, vacuum-packaged, and stored at $2{ }^{\circ} \mathrm{C}$ for analysis of meat quality. For fatty acid analysis, each sample, consisting of approximately $100 \mathrm{~g}$ of tissue, was vacuumpackaged and stored at $20^{\circ} \mathrm{C}$ until the analysis was conducted (approximately 2 wk post-mortem).

\section{Chemical composition}

Protein, fat, moisture, and collagen content were analyzed using the Food Scan ${ }^{\mathrm{TM}}$ Lab 78810 (Foss Tecator Co., Ltd., Denmark), according to the method of the Association of Official Analytical Chemists (AOAC, 2006).

\section{pH}

The $\mathrm{pH}$ was measured using a portable needle-tipped combination electrode (NWKbinar pH-K2, Germany) in the center of the muscle until the muscle was judged to have reached ultimate $\mathrm{pH}$.

\section{Myoglobin content}

The myoglobin $(\mathrm{Mb})$ content was measured as described by Sammel et al. (2002). Five grams of meat was homogenized with $20 \mathrm{~mL}$ of ice-cold DW at 2,270 $\mathrm{g}$ for 30 sec by using a Polytron (PTMR 2100, Kinematica AG, Switzerland) and centrifuged at $2{ }^{\circ} \mathrm{C}$ and $30,000 \mathrm{~g}$ for 30 min (SCR20BA Himac Centrifuge, Hitachi Koki Co., Ltd., Japan). After filtering through a $0.45 \mu \mathrm{m}$ syringe filter, an absorbance value of the supernatant was read at $525 \mathrm{~nm}$ by using a UV/Visible spectrophotometer (ProteomeLab DU800, Beckman Coulter, Inc., USA). The result was calculated as $\mathrm{mg}$ of $\mathrm{Mb}$ per $\mathrm{g}$ of meat using the molecular weight (16,110; Drabkin, 1978) and the millimolar extinction coefficient $(7.6 \mathrm{mM} / \mathrm{cm}$; Bowen, 1949) of $\mathrm{Mb}$.

\section{Meat color, WBSF and cooking loss measurement}

Color values on a freshly cut surface of the WarnerBratzler shear force (WBSF) block were measured using a CR-400 chroma meter (Konica Minolta Sensing, Inc., Japan) for CIE standard lightness $\left(\mathrm{L}^{*}\right)$, redness $\left(\mathrm{a}^{*}\right)$, and 
yellowness $\left(\mathrm{b}^{*}\right)$, after a $30 \mathrm{~min}$ blooming period at $2^{\circ} \mathrm{C}$ (Commission Internationale de I'Eclairage, 1986). WBSF was measured on cooked meat blocks $(50 \times 50 \times 25 \mathrm{~mm})$ in a pre-heated water bath for 40 min until the core temperature reached $80^{\circ}$ and then cooled in running water $\left(c a .18^{\circ} \mathrm{C}\right.$ ) for $30 \mathrm{~min}$ to reach a core temperature below $30^{\circ} \mathrm{C}$. Eight cores of $1.27-\mathrm{cm}$ diameter were made for each sample, and peak force was determined using a Vshaped shear blade of an Instron Universal Testing Machine (Model 5543, USA) with a cross-head speed of 400 $\mathrm{mm} / \mathrm{min}$ (Wheeler et al., 2000). Cooking loss (\%) was calculated as the percentage of weight change during cooking for the WBSF measurement. For cooking loss determination, the samples were freshly cut into blocks and weighed (initial weight). Individual cooked meat block damples were removed from the water-bath, cooled in cold water, and weighed. Cooking loss was then expressed as the percentage of the initial sample weight (Honikel, 1998).

\section{Sarcomere length measurement}

Sarcomere length was measured using a Helium-Neon laser diffraction technique according to the method described by Cross et al. (1981).

\section{Water-holding capacity}

Water-holding capacity (WHC) was measured using the method of Ryoichi et al. (1993). Water-holding capacity (WHC) was determined by a centrifugation method (Kristensen and Purslow, 2001), with the following modification. 0.5 gram of homogenized tissue was placed in a 2 $\mathrm{mL}$ centricon tube (VIDAS, France). The sample containing tube was then placed in a $50 \mathrm{~mL}$ centrifugation tube, heated in a $70^{\circ} \mathrm{C}$ water bath for $30 \mathrm{~min}$, and centrifuged at $100 \mathrm{~g}$ (Hitatchi, SCR20BA, Japan) for $10 \mathrm{~min}$ at room temperature $\left(\mathrm{ca} .18^{\circ} \mathrm{C}\right)$. WHC was expressed as a percentage of weight loss of sample tissue during the centrifugation.

\section{Fatty acids analysis}

Total lipids in beef samples were extracted using chloroform:methanol $(2: 1, \mathrm{v} / \mathrm{v})$ according to the procedure of Folch et al. (1957). An aliquot of the total lipid extract was methylated, as described by Morrison and Smith (1964). Fatty acid methyl esters were analyzed using a gas chromatography (Star 3600, Varian Technologies, USA) fitted with a fused silica capillary column, omegawax 205 (30 $\mathrm{m} \times 0.32 \mathrm{~mm}$ i.d. $0.25 \mu \mathrm{m}$ film thickness). The injection port was heated at $250^{\circ} \mathrm{C}$ and the detector was maintained at $300^{\circ} \mathrm{C}$. Results were expressed as percentages based on the total peak area.

\section{Sensory evaluation}

For sensory evaluation of the loin and top round muscles, the beef strips $(50 \times 75 \times 40 \mathrm{~mm})$ were cooked by placing them on a tin plate equipped with a water jacket (at approximately $245-255^{\circ} \mathrm{C}$ ). Strips were turned at the first pooling of liquid on the surface of the sample or at the start of shrinkage. The cooked strips were immediately served to 7 trained sensory panelists for evaluation. The panelists were asked to score the samples for tenderness, juiciness, flavor, and overall liking. Scoring was performed on a single sheet using four $100 \mathrm{~mm}$ lines from 0 to 100 , with $20 \mathrm{~mm}$ gradients marked. Tenderness ranged from very tough $(0)$ to very tender (100); juiciness ranged from very dry (0) to very juicy (100). Flavor ranged from extreme dislike (0) to extreme liking (100); overall liking ranged from extreme dislike (0) to extreme liking (100).

\section{Statistical analysis}

Each animal within the same slaughtering age group was treated as a replicate. Data were analyzed using the Student-Newman-Keuls' multiple comparison, using the General Linear Model procedure of the SAS program (2010). The significance level was set at $p<0.05$.

\section{Results and Discussion}

\section{Chemical composition}

The moisture, protein, fat, and collagen contents of the loin and top round beef from Holstein calves are shown in Table 1. For both the loin and top round muscles, the moisture contents decreased, whereas the protein and fat contents increased, as the slaughtering ages increased. The moisture contents of the loin $(80.01 \%)$ and top round (78.01\%) samples from the 3 mon-old group were significantly higher than those from the other slaughtering age groups $(p<0.05)$. The loin $(18.49 \%)$ and top round $(20.49 \%)$ muscles from the 3 mon-old group had significantly lower protein contents, whereas the loin $(23.38 \%)$ and top round (23.48\%) muscles from the 12 mon-old group had significantly higher protein contents than those from the other age groups $(p<0.05)$. The fat contents were $2.13 \%$ for loin and $1.31 \%$ for top round muscles of the 12 mon-old group. The fat contents of the loin and top round muscles of the 3 mon-old group were lowest and those from the 12 mon-old group were highest among the 4 slaughtering age groups $(p<0.05)$. However, there was no significant 
Table 1. Chemical composition of loin and top round muscle from Holstein calves with different slaughtering age

\begin{tabular}{|c|c|c|c|c|c|}
\hline Cut & $\begin{array}{c}\text { Age } \\
\text { (mon) }\end{array}$ & $\begin{array}{c}\text { Moisture } \\
(\%)\end{array}$ & $\begin{array}{c}\text { Protein } \\
(\%)\end{array}$ & $\begin{array}{l}\text { Fat } \\
(\%)\end{array}$ & $\begin{array}{c}\text { Collagen } \\
(\%)\end{array}$ \\
\hline \multirow{8}{*}{ Loin } & \multirow{2}{*}{3} & 80.01 & 18.75 & 0.85 & 1.60 \\
\hline & & $\pm 0.26^{* a}$ & $\pm 0.30^{\mathrm{c}}$ & $\pm 0.07^{\mathrm{c}}$ & \pm 0.02 \\
\hline & \multirow{2}{*}{6} & 76.27 & 22.30 & 1.42 & 1.63 \\
\hline & & $\pm 0.20)^{b}$ & $\pm 0.29^{\mathrm{b}}$ & $\pm 0.06^{\mathrm{b}}$ & \pm 0.07 \\
\hline & \multirow{2}{*}{9} & 74.97 & 22.78 & 1.44 & 1.44 \\
\hline & & $\pm 0.19^{c}$ & $\pm 0.28^{\mathrm{ab}}$ & $\pm 0.10^{b}$ & \pm 0.14 \\
\hline & \multirow{2}{*}{12} & 74.08 & 23.38 & 2.13 & 1.59 \\
\hline & & $\pm 0.12^{\mathrm{d}}$ & $\pm 0.06^{\mathrm{a}}$ & $\pm 0.12^{\mathrm{a}}$ & \pm 0.08 \\
\hline \multirow{8}{*}{$\begin{array}{l}\text { Top } \\
\text { round }\end{array}$} & \multirow{2}{*}{3} & 78.01 & 20.49 & 0.64 & 1.28 \\
\hline & & $\pm 0.04^{\mathrm{a}}$ & $\pm 0.64^{\mathrm{c}}$ & $\pm 0.09^{\mathrm{b}}$ & \pm 0.13 \\
\hline & \multirow{2}{*}{6} & 77.01 & 21.44 & 0.91 & 1.59 \\
\hline & & $\pm 0.20^{\mathrm{b}}$ & $\pm 0.16^{\mathrm{bc}}$ & $\pm 0.12^{\mathrm{ab}}$ & \pm 0.09 \\
\hline & \multirow{2}{*}{9} & 74.78 & 22.47 & 1.16 & 1.49 \\
\hline & & $\pm 0.29^{c}$ & $\pm 0.45^{\mathrm{ab}}$ & $\pm 0.15^{\mathrm{ab}}$ & \pm 0.09 \\
\hline & \multirow{2}{*}{12} & 75.26 & 23.48 & 1.31 & 1.63 \\
\hline & & $\pm 0.15^{\mathrm{c}}$ & $\pm 0.09^{\mathrm{a}}$ & $\pm 0.17^{\mathrm{a}}$ & \pm 0.03 \\
\hline
\end{tabular}

*Mean \pm S.E.

${ }^{\mathrm{a}-\mathrm{d}}$ Means in the same column within the same category with different letters are significantly different $(p<0.05)$.

Table 2. Meat color of loin and top round muscle from Holstein calves with different slaughtering age

\begin{tabular}{ccccc}
\hline \hline \multirow{2}{*}{ Cut } & $\begin{array}{c}\text { Age } \\
(\mathrm{mon})\end{array}$ & \multicolumn{3}{c}{ Meat color } \\
\cline { 2 - 5 } & 3 & $41.18 \pm 0.81^{* \mathrm{a}}$ & $6.52 \pm 0.35^{\mathrm{c}}$ & $2.93 \pm 0.17^{\mathrm{b}}$ \\
& 6 & $35.88 \pm 0.62^{\mathrm{b}}$ & $7.99 \pm 0.18^{\mathrm{b}}$ & $2.26 \pm 0.12^{\mathrm{b}}$ \\
Loin & 9 & $31.62 \pm 0.75^{\mathrm{c}}$ & $8.75 \pm 0.38^{\mathrm{b}}$ & $2.97 \pm 0.14^{\mathrm{b}}$ \\
& 12 & $32.11 \pm 0.48^{\mathrm{c}}$ & $11.53 \pm 0.61^{\mathrm{a}}$ & $4.94 \pm 0.30^{\mathrm{a}}$ \\
\hline \multirow{3}{*}{ Top } & 3 & $40.85 \pm 0.81^{\mathrm{a}}$ & $7.81 \pm 0.18^{\mathrm{c}}$ & $4.51 \pm 0.63^{\mathrm{ab}}$ \\
round & 6 & $35.18 \pm 0.62^{\mathrm{b}}$ & $10.17 \pm 0.73^{\mathrm{b}}$ & $3.35 \pm 0.32^{\mathrm{b}}$ \\
& 9 & $31.06 \pm 0.75^{\mathrm{c}}$ & $11.61 \pm 0.63^{\mathrm{b}}$ & $4.54 \pm 0.53^{\mathrm{ab}}$ \\
& 12 & $31.51 \pm 0.36^{\mathrm{c}}$ & $15.03 \pm 0.66^{\mathrm{a}}$ & $5.95 \pm 0.34^{\mathrm{a}}$ \\
\hline
\end{tabular}

$*$ Mean \pm S.E.

${ }^{\mathrm{a}-\mathrm{c}}$ Means in the same column within the same category with different letters are significantly different $(p<0.05)$.

difference in the total collagen contents among the 4 slaughtering age groups $(p>0.05$, Table 1). Although the visible intramuscular fat or marbling is an important meat characteristic that is appreciated by the consumer because of its positive effects on taste, juiciness, and tenderness (Platter et al., 2005), Andreoli et al. (1994) had shown a poor correlation between intramuscular fat content and meat flavor and tenderness in a previous study on veal meat quality. Although the rates of tenderization for veal and beef are the same, the connective tissue apparently contributes little, connective tissues contribute to both the toughness and the amount of tenderizing required, as beef being 1.5 times tougher than veal and requiring twice as much tenderizing (Dransfield et al., 1981). Boccard et al. (1979) has also reported that the collagen content begins to increase significantly from 20 mon of age.

\section{Meat quality}

In terms of meat color, CIE $\mathrm{L}^{*}$ values decreased and CIE $a^{*}$ values increased with an increase in slaughtering age for loin and top round muscles ( $p<0.05$; Table 2$)$. The CIE L* values of the loin (41.18) and top round (40.85) muscles from the 3 mon-old group were significantly higher than those from the other age groups $(p<0.05)$. The CIE a* values of the loin (11.53) and top round (15.03) muscles from the 12 mon-old group were significantly higher than those from the other age groups $(p<0.05)$. The CIE b* values of the loin (4.94) and top round (5.95) muscles from the 12 mon-old group were significantly higher than those from the other age groups $(p<0.05)$. Li et al. (2011) reported that meat color $\left(\mathrm{a}^{*}\right)$ values significantly increased $(p<0.05)$ with age, from 3 to 9 and from 12 to 15 mon in young Qinchuan cattle from China. When the meat color of the heifers $(170 \mathrm{~kg})$ and young bulls (190 $\mathrm{kg}$ ) aged 7-8 mon were compared, young bulls had slightly higher $\mathrm{L}^{*}$ values than heifers, and lower $\mathrm{a}^{*}$ and $\mathrm{b}^{*}$ values (Revilla and Vivar-Quintana, 2005). The meat color, being one of the most important quality criteria in the veal industry, is particularly susceptible to changes in dietary Fe concentrations, of which minimum levels must be maintained to avoid anemia. Consumers are generally believed to assess veal quality on the lean color (Ngapo and Gariépy, 2006). Today, the veal industry relies strongly on lean color for carcass grading and determination of carcass value, as the whiter graded carcasses command greater value. Muscle color varies, and anatomical location of the muscle influences most color traits, including pigment content, reflectance, redness, and the rate of meat discoloration (MacDougall, 1982). Swatland (1985) reported that the LD muscle was largely affected by pigment content, which was strongly correlated with most color parameters, while in the PM muscle ( $m$. psoas major), only redness was correlated with pigment content. Johnson et al. (1992) found a higher correlation $(\mathrm{r}=0.44)$ between muscle pigment and flavor, suggesting that, as the total pigment of veal meat increases, the flavor becomes more intense.

$\mathrm{pH}$, WBS, cooking loss, water holding capacity, and myoglobin content of Holstein calves were compared for loin and top round muscles across the different slaughtering age groups (Table 3 ). $\mathrm{pH}$ values were significantly higher for loin (5.96) and top round (5.67) muscles from the 3 mon-old group than those from the other age groups $(p<0.05)$. The effect of $\mathrm{pH}$ is often referred to in relation 
Table 3. pH, Warner-bratzler shear force (WBSF), cooking loss (CL), sarcomere length (SL), water holding capacity (WHC) and myoglobin contents of loin and top round muscle from Holstein calves with different slaughtering age

\begin{tabular}{cccccccc}
\hline \hline Cut & Age (mon) & pH & Myoglobin (mg/g) & WBSF (kg) & CL (\%) & SL ( $\mu \mathrm{m})$ & WHC (\%) \\
\hline \multirow{5}{*}{ Loin } & 3 & $5.96^{* \mathrm{a}} \pm 0.04$ & $0.13^{\mathrm{d}} \pm 0.00$ & $5.56^{\mathrm{ab}} \pm 1.13$ & $35.44 \pm 0.80$ & $2.50^{\mathrm{a}} \pm 0.13$ & $43.32^{\mathrm{d}} \pm 0.66$ \\
& 6 & $5.58^{\mathrm{b}} \pm 0.02$ & $1.45^{\mathrm{c}} \pm 0.08$ & $9.00^{\mathrm{a}} \pm 0.79$ & $31.50 \pm 1.89$ & $2.13^{\mathrm{a}} \pm 0.17$ & $50.00^{\mathrm{c}} \pm 0.53$ \\
& 9 & $5.56^{\mathrm{b}} \pm 0.06$ & $2.04^{\mathrm{b}} \pm 0.11$ & $8.67^{\mathrm{a}} \pm 1.58$ & $32.81 \pm 0.38$ & $2.09^{\mathrm{a}} \pm 0.09$ & $53.13^{\mathrm{b}} \pm 0.47$ \\
& 12 & $5.44^{\mathrm{b}} \pm 0.02$ & $3.08^{\mathrm{a}} \pm 0.25$ & $3.18^{\mathrm{b}} \pm 0.86$ & $31.63 \pm 0.73$ & $2.36^{\mathrm{a}} \pm 0.06$ & $56.22^{\mathrm{a}} \pm 0.44$ \\
\hline \multirow{5}{*}{ Top round } & 3 & $5.67^{\mathrm{a}} \pm 0.07$ & $0.14^{\mathrm{d}} \pm 0.01$ & $3.45 \pm 0.75$ & $38.74^{\mathrm{a}} \pm 1.47$ & $2.50^{\mathrm{a}} \pm 0.06$ & $48.18^{\mathrm{b}} \pm 1.21$ \\
& 6 & $5.53^{\mathrm{b}} \pm 0.02$ & $1.88^{\mathrm{c}} \pm 0.14$ & $4.70 \pm 0.63$ & $34.92^{\mathrm{b}} \pm 0.92$ & $2.32^{\mathrm{b}} \pm 0.08$ & $49.46^{\mathrm{b}} \pm 1.05$ \\
& 9 & $5.48^{\mathrm{b}} \pm 0.03$ & $2.63^{\mathrm{b}} \pm 0.19$ & $4.79 \pm 0.52$ & $34.47^{\mathrm{b}} \pm 0.71$ & $2.21^{\mathrm{b}} \pm 0.03$ & $52.52^{\mathrm{a}^{\mathrm{a}}} \pm 0.83$ \\
& 12 & $5.42^{\mathrm{b}} \pm 0.02$ & $3.92^{\mathrm{a}} \pm 0.34$ & $4.41 \pm 0.45$ & $35.55^{\mathrm{b}} \pm 0.64$ & $2.15^{\mathrm{b}} \pm 0.02$ & $54.03^{\mathrm{a}} \pm 0.53$ \\
\hline
\end{tabular}

*Mean \pm S.E.

${ }^{a-c}$ Means in the same column within the same category with different letters are significantly different $(p<0.05)$.

to other veal quality characteristics, particularly color. A series of publications have reported on experiments that expressly studied $\mathrm{pH}$ and have included it effects on veal quality (Guignot et al. 1993; Monin, 1993). Muscles have been shown to vary in their rate of decline in $\mathrm{pH}$ post mortem. In LD muscle, a relatively slow $\mathrm{pH}$ decrease is observed, which has less impact on meat color than the pigment content. In contrast, the PM muscle demonstrates a rapid $\mathrm{pH}$ fall, affecting meat color to a larger extent than the pigment content (Eikelenboom and Smulders, 1986). Color was also correlated with the ultimate $\mathrm{pH}$, such that lightness, redness, and reflectance decreased with an increase in the ultimate $\mathrm{pH}$ (Guignot et al., 1993). However, ultimate $\mathrm{pH}$ had no effect on color and cooking loss in veal (Monin, 1993). When Friesian-Holstein and Meuse-Rhine-Yssel breeds calves slaughtered at 25-29 wk in age, the Meuse-Rhine-Yssel calves were heavier and had a slower rate of temperature decline and faster rate of $\mathrm{pH}$ fall (Klont et al., 1999).

The myoglobin contents increased significantly as the slaughtering ages increased for both loin and top round muscles ( $p<0.05$, Table 3 ). The myoglobin comprised 80 $90 \%$ of the color pigment of beef muscle; it bound oxygen and maintained the purple red color of the beef muscle. The main factors responsible for the color of fresh veal are the concentration of the muscle pigment, and the Fe-containing heme protein; the relative proportions of the three forms in which this pigment can occur (purple reduced myoglobin, red oxymyoglobin, and brown metmyoglobin) and its residual quantities of hemoglobin (MacDougall, 1982). The positive correlation between pigment content and color intensity is generally accepted and it is common practice to maintain minimal levels of muscle pigments, by controlling the amount of $\mathrm{Fe}$ in the diet. This practice can produce anemic animals and has resulted in public criticism. However, Fe supplementation of the calves' diet to prevent such deficiency can result in a darker meat of lesser value. Nevertheless, there are discrepancies in the role that myoglobin is considered to play in veal color.

The WBSF values of loin muscles were $5.56 \mathrm{~kg}$ for the 3 mon-old group; this was significantly increased to 9.00 and $8.67 \mathrm{~kg}$ for the 6 - and 9 mon-old groups, respectively. The WBSF values were significantly lower for loin muscles from the 12 mon-old group $(3.18 \mathrm{~kg})$ than those from the 6- and 9 mon-old groups $(p<0.05)$. However, the WBSF values of top round muscles were $3.45-4.79 \mathrm{~kg}$ and they were not significantly different among the 4 slaughtering age groups $(p>0.05)$. In cooking loss, both the loin and top round muscles were significantly higher for the 3 mon-old group than for the other age groups $(p<0.05$, Table 3$)$. The loin muscle had shorter sarcomere lengths in the 6- and 9 mon-old age groups, but this was not statistically significantly different. The sarcomere length of the top round muscle was not significantly different among the 4 different age groups $(p>0.05$; Table $3)$. The WHC of the loin and top round muscles were highest for the 12 mon-old groups among the 4 different age groups $(p<0.05)$. The WHC of the loin muscles were significantly lower for the 3 mon-old group (43.32\%) and that of the top round muscles were significantly lower for the 3- $(48.18 \%)$ and 6 mon-old $(49.46 \%)$ groups than for the other age groups ( $p<0.05$; Table 3 ).

Palatability differences were observed among veal legs from calves slaughtered at average weights of $44.3 \mathrm{~kg}$, $89.5 \mathrm{~kg}$, and $131.2 \mathrm{~kg}$ (Brekke and Wellington, 1972). Differences in WBSF values were observed, in that meat from the lightest group was more tender than that from the other groups. Muscle-specific differences were found when the quality of meat from calves slaughtered at live weights of $238-250 \mathrm{~kg}, 272-286 \mathrm{~kg}$, or $304-318 \mathrm{~kg}$ were compared (Mandell et al., 2001). For both LD and SM 
muscles, the lightness values decreased and redness values increased, resulting in a darker, redder meat, with increasing carcass weight. Moreover, LD muscle from light carcasses had lower cooking loss than that from medium and heavier carcasses.

\section{Fatty acid composition}

The fatty acid compositions (\%) of loin and top round muscles according to different slaughtering ages are shown in Table 4. For loin muscle, the contents of C18:2n6. C20 :4n6, and the total contents of poly-unsaturated fatty acids (PUFA), PUFA/SFA, and n-6 fatty acids were significantly higher for the 3 mon-old group; whereas the contents of C14:0, C16:1n7, C18:1n9, and mono-unsaturated fatty acids (MUFA) were significantly higher for the 12 monold group than for the other age groups $(p<0.05)$. The contents of $\mathrm{C} 18: 3 \mathrm{n} 6$ and $\mathrm{C} 18: 3 \mathrm{n} 3$ were significantly higher and the contents of C16:0 were significantly lower in this group than in the other age groups $(p<0.05)$. For top round muscle, the contents of C20:1n9 fatty acids were significantly higher for the 3 mon-old group. In the same muscle for the 12 mon-old group, the contents of C16:1n7, C18:1n7, C18:1n9, MUFA, and MUFA/saturated fatty acids (SFA) were significantly higher, whereas the contents of $\mathrm{C} 18: 2 \mathrm{n} 6$, and the summation of PUFA, PUFA/SFA, and n-6 fatty acids were significantly lower than for the other age groups $(p<0.05$, Table 4$)$. The contents of C14:0 were significantly lower and the contents of $\mathrm{C} 18: 3 \mathrm{n} 6$ and $\mathrm{C} 18: 3 \mathrm{n} 3$ were significantly higher for the 3 - and 9 mon-old groups than for the 6- and 12 mon-old groups $(p<0.05)$. However, the SFA and n-3 contents were not significantly different for top round muscle among the 4 different age groups ( $p>0.05)$.

The fatty acid compositions between the loin and top round muscles in the same age group were compared (Table 4). In the 9 mon-old group, the contents of C14:0, C18:0, and SFA of the loin muscle were higher than those for top round muscle $(p<0.05)$, whereas the contents of C18:2n6, C18:3n6, C20:4n6, PUFA, and n-6 fatty acids were significantly higher in top round muscle than in loin muscle $(p<0.05)$. In the 12 mon-old group, the contents of SFA for loin muscle were higher than those in top round muscle $(p<0.05)$, whereas the contents of C16:1n7, MUFA, and MUFA/SFA were significantly higher in top round muscle than in loin muscle $(p<0.05)$.

The results of numerous studies have confirmed that fatty acid composition can be influenced by individual factors, such as diet, breed, and age of the animal (Smith et al., 2009), and level of fatness (Nürnberg et al., 1998).
Table 4. Fatty acid composition (\%) in loin and top round from calves with different slaughtering age

\begin{tabular}{|c|c|c|c|}
\hline \multirow{2}{*}{ Items } & \multirow{2}{*}{$\begin{array}{l}\text { Age } \\
\text { (mon) }\end{array}$} & \multicolumn{2}{|c|}{ Cut } \\
\hline & & Loin & Top round \\
\hline \multirow{4}{*}{ C14:0 (Myristic acid) } & 3 & $2.81 \pm 0.17^{b}$ & $2.54 \pm 0.14^{b}$ \\
\hline & 6 & $4.23 \pm 0.29^{\mathrm{a}}$ & $4.09 \pm 0.24^{\mathrm{a}}$ \\
\hline & 9 & $4.40 \pm 0.33^{\mathrm{aA}}$ & $2.86 \pm 0.23^{\mathrm{bB}}$ \\
\hline & 12 & $4.77 \pm 0.21^{\mathrm{a}}$ & $4.16 \pm 0.18^{\mathrm{a}}$ \\
\hline \multirow{4}{*}{ C16:0 (Palmitic acid) } & 3 & $30.24 \pm 1.14^{\mathrm{a}}$ & $29.98 \pm 0.34^{\mathrm{a}}$ \\
\hline & 6 & $29.47 \pm 0.75^{\mathrm{ab}}$ & $29.12 \pm 0.52^{\mathrm{a}}$ \\
\hline & 9 & $27.17 \pm 1.22^{\mathrm{b}}$ & $27.38 \pm 0.67^{\mathrm{b}}$ \\
\hline & 12 & $31.59 \pm 0.58^{\mathrm{a}}$ & $29.68 \pm 0.60^{\mathrm{a}}$ \\
\hline \multirow{4}{*}{$\begin{array}{c}\mathrm{C} 16: \ln 7 \\
\text { (Palmitoleic acid) }\end{array}$} & 3 & $1.24 \pm 0.16^{\mathrm{c}}$ & $1.36 \pm 0.08^{\mathrm{c}}$ \\
\hline & 6 & $2.80 \pm 0.12^{\mathrm{b}}$ & $3.10 \pm 0.07^{\mathrm{b}}$ \\
\hline & 9 & $3.21 \pm 0.21^{\mathrm{ab}}$ & $3.39 \pm 0.38^{b}$ \\
\hline & 12 & $3.44 \pm 0.21^{\mathrm{aB}}$ & $4.43 \pm 0.25^{\mathrm{aA}}$ \\
\hline \multirow{4}{*}{ C18:0 (Stearic acid) } & 3 & $18.14 \pm 1.41$ & $17.36 \pm 0.51^{\mathrm{a}}$ \\
\hline & 6 & $19.25 \pm 0.51^{\mathrm{A}}$ & $16.88 \pm 0.26^{\mathrm{a} B}$ \\
\hline & 9 & $19.11 \pm 1.20^{\mathrm{A}}$ & $13.06 \pm 1.08^{\mathrm{bB}}$ \\
\hline & 12 & $16.88 \pm 0.79$ & $13.63 \pm 0.82^{b}$ \\
\hline \multirow{4}{*}{ C18:1n9 (Oleic acid) } & 3 & $29.75 \pm 2.47^{b}$ & $28.96 \pm 2.06^{b}$ \\
\hline & 6 & $30.59 \pm 0.80^{\mathrm{b}}$ & $31.56 \pm 0.97^{\mathrm{b}}$ \\
\hline & 9 & $30.28 \pm 2.42^{\mathrm{b}}$ & $31.94 \pm 1.32^{\mathrm{b}}$ \\
\hline & 12 & $36.77 \pm 0.57^{\mathrm{a}}$ & $40.77 \pm 1.64^{\mathrm{a}}$ \\
\hline \multirow{4}{*}{$\begin{array}{c}\mathrm{C} 18: \ln 7 \\
\text { (trans-vaccenic acid) }\end{array}$} & 3 & $0.11 \pm 0.01$ & $0.11 \pm 0.00^{b}$ \\
\hline & 6 & $0.14 \pm 0.01$ & $0.15 \pm 0.01^{b}$ \\
\hline & 9 & $0.18 \pm 0.02$ & $0.13 \pm 0.02^{\mathrm{b}}$ \\
\hline & 12 & $0.17 \pm 0.02$ & $0.27 \pm 0.03^{\mathrm{a}}$ \\
\hline \multirow{4}{*}{$\begin{array}{c}\text { C18:2n6 } \\
\text { (Linoleic acid) }\end{array}$} & 3 & $10.75 \pm 1.52^{\mathrm{a}}$ & $12.43 \pm 1.34^{\mathrm{a}}$ \\
\hline & 6 & $9.00 \pm 1.26^{\mathrm{a}}$ & $9.65 \pm 0.82^{\mathrm{a}}$ \\
\hline & 9 & $9.37 \pm 0.75^{\mathrm{aB}}$ & $11.14 \pm 0.98^{\mathrm{aA}}$ \\
\hline & 12 & $4.03 \pm 0.41^{\mathrm{b}}$ & $4.16 \pm 0.55^{\mathrm{b}}$ \\
\hline \multirow{4}{*}{$\begin{array}{c}\text { C18:3n6 } \\
\text { (gamma-linolenic acid) }\end{array}$} & 3 & $0.12 \pm 0.01^{b}$ & $0.14 \pm 0.02^{\mathrm{ab}}$ \\
\hline & 6 & $0.11 \pm 0.01^{\mathrm{b}}$ & $0.11 \pm 0.01^{\mathrm{bc}}$ \\
\hline & 9 & $0.10 \pm 0.00^{\mathrm{aB}}$ & $0.15 \pm 0.16^{\mathrm{aA}}$ \\
\hline & 12 & $0.08 \pm 0.00^{\mathrm{c}}$ & $0.07 \pm 0.01^{\mathrm{c}}$ \\
\hline \multirow{4}{*}{$\begin{array}{c}\text { C18:3n3 } \\
\text { (Linolenic acid) }\end{array}$} & 3 & $0.36 \pm 0.02^{b}$ & $0.46 \pm 0.08^{\mathrm{a}}$ \\
\hline & 6 & $0.26 \pm 0.02^{b}$ & $0.25 \pm 0.03^{b}$ \\
\hline & 9 & $0.41 \pm 0.04^{\mathrm{a}}$ & $0.44 \pm 0.05^{\mathrm{a}}$ \\
\hline & 12 & $0.22 \pm 0.01^{\mathrm{b}}$ & $0.22 \pm 0.03^{\mathrm{b}}$ \\
\hline \multirow{4}{*}{$\begin{array}{c}\mathrm{C} 20: \ln 9 \\
(\text { cis-11-eicosenoic acid) }\end{array}$} & 3 & $1.98 \pm 1.08$ & $0.61 \pm 0.13^{\mathrm{a}}$ \\
\hline & 6 & $0.36 \pm 0.05$ & $0.34 \pm 0.03^{\mathrm{b}}$ \\
\hline & 9 & $0.27 \pm 0.06$ & $0.40 \pm 0.06^{\mathrm{b}}$ \\
\hline & 12 & $0.27 \pm 0.02$ & $0.34 \pm 0.02^{\mathrm{b}}$ \\
\hline \multirow{4}{*}{$\begin{array}{c}\mathrm{C} 20: 4 \mathrm{n} 6 \\
\text { (Arachidonic acid) }\end{array}$} & 3 & $4.17 \pm 0.45^{\mathrm{aA}}$ & $5.67 \pm 0.66^{\mathrm{aB}}$ \\
\hline & 6 & $3.27 \pm 0.42^{\mathrm{ab}}$ & $4.13 \pm 0.27^{\mathrm{a}}$ \\
\hline & 9 & $2.44 \pm 0.29^{\mathrm{bcB}}$ & $5.80 \pm 0.54^{\mathrm{aA}}$ \\
\hline & 12 & $1.52 \pm 0.29^{\mathrm{c}}$ & $1.99 \pm 0.55^{\mathrm{b}}$ \\
\hline \multirow{4}{*}{ SFA $^{1)}$} & 3 & $51.18 \pm 2.45$ & $49.88 \pm 0.96$ \\
\hline & 6 & $52.96 \pm 1.39$ & $50.10 \pm 0.84$ \\
\hline & 9 & $55.20 \pm 0.53^{\mathrm{A}}$ & $49.34 \pm 1.13^{\mathrm{B}}$ \\
\hline & 12 & $53.24 \pm 1.29^{\mathrm{A}}$ & $47.47 \pm 1.29^{\mathrm{B}}$ \\
\hline \multirow{4}{*}{ MUFA $^{2)}$} & 3 & $33.09 \pm 1.68^{b}$ & $31.04 \pm 2.15^{b}$ \\
\hline & 6 & $33.89 \pm 0.88^{\mathrm{b}}$ & $35.16 \pm 1.05^{\mathrm{b}}$ \\
\hline & 9 & $35.41 \pm 2.36^{\mathrm{b}}$ & $32.30 \pm 1.50^{\mathrm{b}}$ \\
\hline & 12 & $40.66 \pm 0.73^{\mathrm{aB}}$ & $45.82 \pm 1.84^{\mathrm{aA}}$ \\
\hline
\end{tabular}


Table 4. Continued

\begin{tabular}{cccc}
\hline \hline \multirow{2}{*}{ Items } & Age & \multicolumn{2}{c}{ Cut } \\
\cline { 3 - 4 } & $($ mon $)$ & Loin & Top round \\
\hline & 3 & $15.73 \pm 1.83^{\mathrm{a}}$ & $19.07 \pm 2.24^{\mathrm{a}}$ \\
PUFA $^{3)}$ & 6 & $13.16 \pm 1.73^{\mathrm{ab}}$ & $14.75 \pm 1.10^{\mathrm{a}}$ \\
& 9 & $15.36 \pm 1.05^{\mathrm{bcB}}$ & $18.36 \pm 1.83^{\mathrm{aA}}$ \\
& 12 & $6.10 \pm 0.72^{\mathrm{c}}$ & $6.71 \pm 1.22^{\mathrm{b}}$ \\
\hline \multirow{3}{*}{ MUFA/SFA } & 3 & $0.66 \pm 0.05$ & $0.62 \pm 0.04^{\mathrm{b}}$ \\
& 6 & $0.64 \pm 0.02$ & $0.70 \pm 0.03^{\mathrm{b}}$ \\
& 9 & $0.68 \pm 0.07$ & $0.83 \pm 0.05^{\mathrm{b}}$ \\
& 12 & $0.76 \pm 0.03^{\mathrm{B}}$ & $0.97 \pm 0.06^{\mathrm{aA}}$ \\
\hline & 3 & $0.31 \pm 0.04^{\mathrm{a}}$ & $0.38 \pm 0.05^{\mathrm{a}}$ \\
PUFA/SFA & 6 & $0.25 \pm 0.04^{\mathrm{ab}}$ & $0.30 \pm 0.02^{\mathrm{a}}$ \\
& 9 & $0.17 \pm 0.02^{\mathrm{bcB}}$ & $0.37 \pm 0.05^{\mathrm{aA}}$ \\
& 12 & $0.14 \pm 0.03^{\mathrm{c}}$ & $0.14 \pm 0.03^{\mathrm{b}}$ \\
\hline & 3 & $15.36 \pm 1.81^{\mathrm{a}}$ & $18.55 \pm 2.11^{\mathrm{a}}$ \\
& 6 & $12.79 \pm 1.71^{\mathrm{ab}}$ & $14.32 \pm 1.07^{\mathrm{a}}$ \\
& 9 & $9.10 \pm 0.65^{\mathrm{bcB}}$ & $17.71 \pm 1.02^{\mathrm{aA}}$ \\
& 12 & $5.81 \pm 0.70^{\mathrm{c}}$ & $6.39 \pm 1.17^{\mathrm{b}}$ \\
\hline & 3 & $0.36 \pm 0.02$ & $0.53 \pm 0.14$ \\
& 6 & $0.37 \pm 0.03$ & $0.42 \pm 0.04$ \\
& 9 & $0.63 \pm 0.06$ & $0.73 \pm 0.07$ \\
& 12 & $0.29 \pm 0.02$ & $0.31 \pm 0.05$ \\
\hline & & &
\end{tabular}

${ }^{\mathrm{a}-\mathrm{b}}$ Means \pm S.E. in the same column with different superscripts differ significantly $(p<0.05)$.

${ }^{A-C}$ Means \pm S.E. in the same row with different superscripts differ significantly $(p<0.05)$.

${ }^{1)}$ Saturated fatty acids.

${ }^{2)}$ Monounsaturated fatty acids.

${ }^{3)}$ Polyunsaturated fatty acids.

Grain diets result in high concentrations of n-6 PUFA, while grass diets increase muscle concentrations of n-3 PUFA (Enser et al., 1998). Japanese Black cattle produce carcasses that have adipose tissues with higher percentages of MUFA than do Holstein, Japanese Brown, Charolais, or Angus steers (Oka et al., 2002). The fatty acid composition of the meat may also be influenced by changes in age and fatness. Thus, the proportion of PUFA in muscle decreases, while the deposition of intramuscular neutral lipids increases, with animal age (Wood et al., 2003). Kim et al. (1996) reported that the levels of SFA increase and those of UFA decrease with increasing slaughtering age when the fatty acid composition of Holstein steers (17-19 mon old) were compared at different slaughtering ages. The SFA and MUFA contents increase faster with fatness levels than do the PUFA contents (De Smet et al., 2004).

On the other hand, the fatty acid composition influences the organoleptic characteristics of meat. Increased unsaturation results in greater flavor changes in ruminants, including beef, than it does in pork (Melton, 1990). Additionally, Fisher et al. (2000) found that flavor intensity correlates positively with linolenic acid (C18:3n3) and negatively with linoleic acid (C18:2n6) content. MUFA in meat have been shown to influence beef palatability (Westerling and Hedrick, 1979). Wood et al. (2003) reported that the recommended ratio of PUFA to SFA (P:S) in the fatty acid intake from food should be above 0.4 , and that some meats naturally have a P:S ratio of around 0.1 . In this study, the overall low P:S ratio for loin and top round are likely due to low intramuscular fat contents of young animals.

\section{Sensory evaluation}

The results of the sensory evaluation are shown in Table 5. There was no significant difference in juiciness scores in the loin beef among the 4 slaughtering age groups ( $p>$ $0.05)$. However, the loin samples from the 3- and 12 monold groups had significantly higher scores in terms of tenderness (70.72 and 70.88, respectively) and overall likeness (64.44 and 68.81, respectively) than those from the other slaughtering age groups $(p<0.05)$. The flavor likeness was also significantly higher in the loin samples from the 12 mon-old group than from the other slaughtering age groups

Table 5. Sensory evaluation of loin and top round muscles from Holstein calves with different slaughtering age

\begin{tabular}{ccccc}
\hline \hline Age (mon) & Tenderness & Juiciness & Flavor-likeness & Overall likeness \\
\hline Loin & & & \\
3 & $70.72 \pm 3.56^{* \mathrm{a}}$ & $66.93 \pm 3.11$ & $64.34 \pm 2.82^{\mathrm{b}}$ & $64.44 \pm 3.21^{\mathrm{a}}$ \\
6 & $57.25 \pm 2.81^{\mathrm{b}}$ & $63.58 \pm 3.65$ & $65.68 \pm 2.95^{\mathrm{b}}$ & $57.30 \pm 3.03^{\mathrm{b}}$ \\
9 & $57.31 \pm 2.65^{\mathrm{b}}$ & $65.18 \pm 3.02$ & $64.92 \pm 2.35^{\mathrm{b}}$ & $58.14 \pm 2.69^{\mathrm{b}}$ \\
12 & $70.88 \pm 2.22^{\mathrm{a}}$ & $60.56 \pm 3.74$ & $68.13 \pm 2.48^{\mathrm{a}}$ & $68.81 \pm 2.04^{\mathrm{a}}$ \\
\hline & & & \\
6 & $67.59 \pm 2.69^{\mathrm{a}}$ & $71.41 \pm 3.2^{\mathrm{a}}$ & $66.99 \pm 1.93$ & $64.96 \pm 3.19^{\mathrm{b}}$ \\
9 & $58.93 \pm 2.15^{\mathrm{b}}$ & $61.25 \pm 1.88^{\mathrm{c}}$ & $65.08 \pm 2.24$ & $60.03 \pm 2.04^{\mathrm{b}}$ \\
12 & $65.99 \pm 2.29^{\mathrm{a}}$ & $66.60 \pm 2.52^{\mathrm{b}}$ & $67.74 \pm 2.28$ & $67.17 \pm 2.21^{\mathrm{a}}$ \\
\hline
\end{tabular}

*Mean \pm S.E.

${ }^{\mathrm{a}, \mathrm{b}}$ Means in the same column within the same category with different letters are significantly different $(p<0.05)$. 
$(p<0.05)$. The top round samples from the 3-, 9- and 12 mon-old groups had significantly higher scores for tenderness than those from the 6 mon-old group $(p<0.05)$. The overall likeness scores were also significantly higher for top round samples from the 9- and 12 mon-old groups than those from the 3- and 6 mon-old groups $(p<0.05)$. However, the top round samples from the 3-mon-old groups had highest scores (71.41) and those from the 6-mon-old groups had lowest scores (61.25) in juiciness among 4 slaughtering groups $(p<0.05)$. There were no significant differences in juiciness and flavor likeness for top round samples among the 4 slaughtering age groups $(p>0.05)$.

Consumers rate tenderness as the primary sensory trait when making purchasing decisions (Mennecke et al., 2007). Very few publications have dealt with veal or calf beef in terms of sensory evaluation. The meat from a group of penned calves showed reduced WBSF values and was more tender than that from individually crated 5-mon-old Holstein male calves (Angrighetto et al., 1999). Musclespecific differences were found when comparing the quality of meat from calves slaughtered at live weights of 238-250, 272-286, or 304-318 kg (Mandell et al., 2001). Weight class did not affect tenderness values; however, LD muscle from light carcasses was juicier than that from medium and heavier carcasses and the SM muscle from medium carcases was less flavorsome than that from heavy carcasses.

\section{Conclusions}

Consumers rate tenderness as the primary sensory trait when making purchasing decisions, yet very few publications have dealt with veal or calf beef in terms of sensory evaluation. The results of this study demonstrated that calf beef had acceptable meat quality and sensory properties. Especially, the loin and top round muscles from the 12 mon-old group had desirable quality properties in meat color (CIE a*), low WBSF values, high WHC and sensory properties when compared to the other age groups. The advantages of savings in feed cost should be considered for Holstein farmers, by advancing slaughtering time from 20 to 22 mon to less than 12 mon of age. Therefore, the production of Holstein calf beef could contribute to discrimination of Holstein beef from Hanwoo and imported beef in the domestic beef market.

\section{Acknowledgements}

This work was carried out with the support of "Cooper- ative Research Program" for Agriculture Science and Technology Development (PJ. 00919502), Rural Development Administration, Republic of Korea.

\section{References}

1. Andreoli, D., Cozzi, G., and Gottardo, F. (1994) Effetto del tipo genetico nella produzione dal vitello a carne bianca: 2 . Caratteristiche qualitative delle carni. Atti 48 Convegno S.I. S. Vet. Giardini Naxis, pp. 1781-1785.

2. Andrighetto, I., Gottardo, F., Andrewoli, D., and Cozzi, G. (1999) Effect of type of housing on veal calf growth performance, behaviour and meat quality. Liv. Prod. Sci. 57, 137145

3. AOAC (2006) Official Methods of Analysis. 15th ed., Association of Official Analytical Chemists, Washington, D.C., pp. 210-219.

4. Aus-Meat Limited (2005) Handbook of Australia meat. Available from www.ausmeat. com.au (Accessed on Jul. 2, 2014).

5. Boccard, R. L., Naude, R. T., Crouse, D. E., Shim, M. C., Venter, H. J., and Rossow, F. I. (1979) The influence of age, sex and breed of cattle on their muscle characteristics. Meat Sci. 3, 261-265.

6. Bowen, W. J. (1949). The absorption spectra and extinction coefficients of myoglobin. J. Biol. Chem. 179, 235-245.

7. Brekke, C. J. and Wellington, G. H. (1972) Effect of animal weight on palatability of veal leg roasts. J. Anim. Sci. 35, 937940.

8. Canadian Agri-Food Research Council, Recommended Code of Practice for the Care and Handling of Farm Animals, Veal Calves (1998) Available from http://www.carc-crac.ca/english/ codes_of_practice/vealcde.htm (Accessed on Dec. 12, 2013)

9. CIE (1986) Colorimetry. 2nd ed., Commission Internationale de I'Eclairage, Publication CIE No. 15.2. Vienna.

10. Cross, H. R., West, R. L., and Dutson T. R. (1981) Comparison of methods for measuring sarcomere length in beef semitendinosus muscle. Meat Sci. 5, 261-266.

11. De Smet. S., Raes, K., and Demeyer, D. (2004) Meat fatty acid composition as affected by fatness and genetic factors: a review. Animal Research 53, 81-98.

12. Drabkin, D. L. (1978). Selected landmarks in the history of porphyrins and their biologically functional derivatives. In D. Dolphin (Ed.), The porphyrins (pp. 2983). New York: Academic Press, Inc.

13. Dransfield, E., Jones, R. C. D., and MacFie, H. J. H. (1981) Tenderising in $m$. longissimus dorsi of beef, veal, rabbit, lamb and pork. Meat Sci. 5, 139-147.

14. Eikelenboom, G., Laurijsen, H. A. J., van Velthuysen, A., and Garssen, G. J. (1988) Veal colour in relation to production traits and minerals in muscle. Fleischwirt 68, 489-490.

15. Enser, M., Hallett, K. G., Hewitt, B., Fursey, G. A., Wood, J. D., and Harrington, G. (1998) Fatty acid content and composition of UK beef and lamb muscle in relation to production system and implications for human nutrition. Meat Sci. 49, 329-341.

16. European Commission, Opinion of the Scientific Committee 
on Veterinary Measures Relating to Public Health on Revision of Meat Inspection in Veal Calves (2003) Available: from http://europa.eu.int/comm/food/fs/sc/scv/out65_en.pdf (accessed on Dec. 12, 2013)

17. Fisher, A.V., Enser, M., Richardson, R. I., Wood, J. D., Nute, G. R., Kurt, E., Sinclair, L. A., and Wilkinson, R. G. (2000) Fatty acid composition and eating quality of lamb types derived from four diverse breed $\times$ production systems. Meat Sci. 55, 141-147.

18. Folch, J., Lees, M., and Stanley, G. H. S. (1957) A simple method for the isolation and purification and total lipids from animal tissues. J. Biol. Chem. 226, 497-500.

19. Guignot, F., Touraille, C., Ouali, M., and Monin, G. (1993) Relationships between post-mortem $\mathrm{pH}$ changes and some traits of sensory quality in veal. Meat Sci. 37, 3133-3139.

20. Honikel, K. O. (1998) Reference methods for the assessment of physical characteristics of meat. Meat Sci. 49, 447-457.

21. Johnson, D. D., Van Horn, H. H., West, R. L., and Harris, Jr. B. (1992) Effect of the calf management on carcass characteristics and palatability traits of veal calves. J. Dairy Sci. $\mathbf{7 5}$, 2799-2804.

22. KAPE (2014) Animal Products Grading Statistical Yearbook, Korea Institute for Animal Product's Quality Evaluation, Gunpo.

23. Kim, D. G., Jung, K. K., Sung, S. K., Choi, C. B., Kim, S. K., Kim, D. Y., and Choi, B. J. (1996) Effects of age on the carcass characteristics of Hanwoo and Holstein steers. Agri. Sci. Lib. 38, 239-248.

24. Klont, R. E., Barnier, V. M. H., Smulders, F. J. M., van Dijk, A., Hoving-Bolink, A. H., and Eikelenboom, G. (1999) Postmortem variation in $\mathrm{pH}$, temperature and colour profiles of veal carcasses in relation to breed, blood haemoglobin content, and carcass characteristics. Meat Sci. 53, 195-202.

25. Kristensen, L. and Purslow, P. P. (2001) The effect of ageing on the water-holding capacityof pork: role of cytoskeletal proteins. Meat Sci. 58, 17-23.

26. Le Neindre, P. (1993) Evaluating housing systems for veal calves. J. Anim. Sci. 71, 1345-1354.

27. Li, L. O., Tian, W. Q., and Zan, K. S. (2011) Effects of age on quality of beef from Qinchuan cattle carcass. Agric. Sci. (China). 10, 1765-1771.

28. MacDougall, D. B. (1982) Changes in the colour and opacity of meat. Food Chem. 9, 75-88.

29. Mandell, I. B., Maclaurin, T., and Buttenhan, S. (2001) Effect of carcass weight class and post-mortem aging on carcass characteristics and sensory attributes in grain fed veal. $J$. Food Sci. 66, 762-769.

30. Melton, S. L. (1990) Effect of feeds on flavor of red meat : A review. J. Anim. Sci. 68, 4421-4435.

31. Mennecke, B. E., Townsend, A. M., Hayes, D. J., and Lonergan, S. M. (2007) A study of factors that influence consumer attitudes toward beef products using the conjoint market ana- lysis tool. J. Anim. Sci. 85, 2639-2659.

32. Monin, G. (1993) pH et qualities sensorielles de la viande de veau. Viandes et produits carnés 14, 43-47.

33. Morrison, W. R. and Smith, L. M. (1964) Preparation of fatty acid methylesters and dimethylacetals from lipid with boron fluoridemethanol. J. Lipid Resour. 5, 600-608.

34. Ngapo, T. M. and Gariépy, C. (2006) Factors affecting the meat quality of veal. J. Sci. Food Agri. 86, 1412-1431.

35. NLCF (1998) Korean carcass grading standard, National Livestock Cooperatives Federation, Seoul.

36. Nürnberg, K., Wegner, J., and Ender, K. (1998) Factors influencing fat composition in muscle and adipose tissue of farm animals. Liv. Prod. Sci. 56, 145-156.

37. Oka, A., Iwaki, F., Dohgo, T., Ohiagaki, S., Noda, M., and Shiozuki, T. (2002) Genetic effects on fatty acid composition of carcass fat of Japanese Black Wagyu stters. J. Anim. Sci. 80, 1005-1011.

38. Platter, W. J., Tatum, J. D., Belk, K. E., Koontz, S. R., Chapman, P. L., and Smith, G. C. (2005) Effects of marbling and shear force on consumers' willingness to pay for beef strip loin steaks. J. Anim. Sci. 83, 890-899.

39. Revilla, I. and Vivar-Quintana, A. M. (2006) Effect of breed and ageing time on meat quality and sensory attributes of veal calves of the "Ternera de Aliste" quality level. Meat Sci. 73, 189-195.

40. Sammel, L. M., Hunt, M. C., Kropf, D. H., Hachmeister, K. A., and Johnson, D. E. (2002) Comparison of assays for metmyoglobin reducing ability in beef inside and outside semimembranosus muscle. J. Food Sci. 67, 978-984.

41. SAS (2010) SAS/STAT Software for PC. Release 9.2, SAS Institute Inc., Cary, NC, USA.

42. Smith, S. B., Gill, C. A., Lunt, D. K., and Brooks, M. A. (2009) Regulation of fat and fatty acid composition in beef cattle. Asian-Australas. J. Anim. Sci. 22, 1225-1233.

43. Swatland, H. J. (1985) Measurement of veal colour by fiber optic spectrophotometry. J. Food Sci. 50, 1489-1490.

44. Wilson, L. L. Special-fed veal research. Lancaster Farming. Agricultural Articles (2004) Available from http://lancasterfarming.com/17.html (accessed on Dec. 12, 2013)

45. Westerling, D. B. and Hedrick, H. B. (1979) Fatty acid composition of bovine lipids as influenced by diet, sex and anatomical location and relationship to sensory characteristics. $J$. Anim. Sci. 48, 1343-1348.

46. Wheeler, T. L., Shackelford, S. D., and Koohmaraie. M. (2000) Variaton in proteolysis, sarcomere length, collagen content, and tenderness among major pork muscles. J. Anim. Sci. 78, 958-965.

47. Wood, J. D., Richardson, R. I., Nute, G. R., Fisher, A. V., Campo, M. M., Kasapidou, E., Sheard, P. R., and Enser, M. (2003) Effect of fatty acids on meat quality: review. Meat Sci. 66, 21-32.

(Received 2014.7.14/Revised 2014.8.26/Accepted 2014.9.18) 